\title{
AFRO-CENTRISM: THE CHALLENGE OF SOCIAL DEVELOPMENT
}

\section{K Osei-Hwedie}

\section{INTRODUCTION}

African nations seek to escape from poverty, disease, ignorance, inequality and lack of opportunity. Despite massive investments in socio-economic development, the masses in many African countries still remain ill-fed, ill-housed, under-educated and vulnerable to preventable diseases such as HIV/AIDS, and malaria. The continent is characterised by increasing economic deprivation, generalised misery, a high incidence of poverty, environmental destruction and diminishing food security. This is underscored by the fact that the number of people living in extreme poverty (on U\$1 or less a day) rose from 217 million in 1990 to 290 million in 2000 (Economic Commission for Africa (ECA), 2005). Governments and other stakeholders are constantly searching for better and more effective ways to tackle these problems in order to improve the welfare of their people.

Until recently Western values and ideas were seen as the only sources of development. However, the importance of other values and norms is evident. Other traditions, as exhibited by ubuntu/botho, demonstrate that flexibility and accommodation are critical in all aspects of development. Mangaliso (2005) emphasises that in a globalising world economy, nations will increasingly be hard pressed to develop unique resources that they can use as their sources of competitive advantage. It seems that in the case of (Southern) Africa qualities and values embodied in ubuntu/botho represent an intangible resource that potentially can elevate (Southern) Africa to a higher level of social stability and development.

Successful development requires the effective harnessing, harmonising and rationalising of indigenous cultures in order to appreciate their added value instead of suppressing them. Traditionally, Western-based concepts and processes have been allowed to unconditionally dominate development activities around the world with little regard for indigenous cultures. The challenge, therefore, is to become familiar with indigenous cultures and their core values, and appreciate and incorporate them into development policies and processes. For social work research, for example, the challenge is to fashion a new agenda that incorporates the ideas enshrined in ubuntu/botho as a source of "sustainable competitive advantage" (Mangaliso, Mangaliso \& Weir, 2005:807) in the process of social development.

Social development has ushered in an ideology emphasising equality of all people, social justice, human rights, access to services, opportunities and resources, and more importantly, a new and concerted drive towards poverty reduction. However, social development, as a community-driven process, takes place within a national and international context. Thus, although the emphasis must be on using local knowledge, norms, values and processes, these must take account of external values, technologies and philosophies of development.

The article, therefore, discusses the challenges of social development based on African values, and examines its prospects in the process of balancing local and foreign values, and norms that often seem contradictory. For example, can social development be re-conceptualised with botho or ubuntu as a core organising principle in a neo-liberal political and economic context? The main questions, therefore, relate to how core values can play meaningful and effective roles in achieving the goals and visions of social development; whether these values are suitable in contemporary Africa; whether African tradition(s) are at variance with modernity; and whether African cultural values can be assessed and interpreted to effectively contribute to African development? The discussion of African views as the basis for social development is 
an "integral aspect of the indigenisation debate" (Gray \& Allegritti, 2002:324). It is assumed that there are differences between African and Western cultures and values, and that even though what is African or Western is contested, there are enough commonalities to enable us accept a certain level of cultural unity among them. It is in this context that the article refers to Africa and the West.

\section{CONCEPTUAL ISSUES}

\section{Ubuntu/Botho}

Ubuntu/Botho means "humanness". It is a cultural value that places humans at the centre of the universe, without making them superior to all things. It is the expression of the symbiotic nature of existence between humans; between humans and the supernatural; and between humans, the supernatural and the environment. It is characterised by collective existence and experience, which translate into communalism. As a holistic approach to life, it places the emphasis on unity and the incorporation of all parts. It is embedded in an ideology which links individuals to the extended families and communities. It is rooted in respect for customs that maintain a strong work ethic, respect and the pursuit of the common good, as well as the promotion and maintenance of harmony, peace and progress (Mangaliso, 2005). It is in the context of ubuntu/botho that Afro-centrism becomes a framework for development.

\section{Afro-centrism}

Afro-centrism, which is also referred to in the literature as afro-centricity, "literally means placing African ideas at the center of any analysis that involves African culture and behavior" (Asante, 1998:2). As a belief in the centrality of Africans in postmodern history, Afro-centrism is described as one of the African cultural systems manifested in diversities and modified according to specific histories (Asante, 1980). Afro-centrism is also described as a worldview through which people should interpret events and define reality, rather than seeking to attain equal rights, economic development and the advancement of oppressed groups without fundamentally affirming tradition and validating or promoting people's cultural worldviews (Schiele, 2000). Asante (1999) further underscores the educational function of afro-centrism in expanding dialogue and widening the affirmation of all people in their cultural heritage, based on the idea of African agency. This implies accepting and treating all people with dignity and respect, and affirming the equality of humanity.

The essence of afro-centrism, as an alternative worldview, seems to be founded on the need to counter what its proponents described as a hegemony resulting from the economic and cultural influences of the affluent countries of the West on African people. Without reciprocity, the current global influences appear to be militating against any realisation of cultural autonomy. In this regard, Africa is said to be experiencing a harsher situation than other parts of the world (Ahluwalia \& Nursey-Bray, 1997).

Afro-centrism, as a paradigm of human services, is better appreciated and understood by examining Africa's traditional themes and associated values that enhance a rich tradition of group consciousness, cohesiveness and responsibility in matters of social welfare (Schiele, 2000). Citing Williams, Schiele (2000) notes that, philosophically, the African economic concept of profit implies a surplus only after the human needs of all in the community have been addressed. Also emphasised in this context are three important African tenets: namely that human identity is conceived through an extended kinship system; poverty is unnecessary and intolerable; and government and individual responsibility are mutually dependent and affirmed (Schiele, 2000:38). 


\section{Social Development}

Although there may be no agreed definition among different authors, according to Gray, Mazibuko and O'Brien (1996), social development refers to a process of change starting from an individual's development of confidence, cooperativeness, awareness and skills. Social development also refers to a form of human welfare that seeks to harmonise social policy and economic development. As an approach to social welfare, social development offers an effective response to social problems though a comprehensive and universalistic focus on community processes and structures. Through participation in the decision making process by ordinary people, social development enhances a sense of community, which strengthens community bonds (Midgley, 1986; 1995). Social development can also be defined as "a dynamic way of organizing resources and human interactions to create opportunities through which the potential of all people-individually and collectively can develop to the full" (Dominelli, 1997:29). Yiman (1990:69) defines social development as:

... that aspect of overall development brought about by the coordinated effort of an interdisciplinary team of experts from governmental and non-government institutions, with the active participation of the people as a whole, and is concerned with the qualitative and quantitative changes in social conditions aimed at enhancing levels of improvement in the level of living of individuals, groups and communities through such measures as social policy, social welfare, social services, social security, social administration, social work, community development and institution building through proper utilization of available resources.

Social development, therefore, aims at the satisfaction of basic human needs, social justice and the quest for peace. It is a process through which people are empowered to realize their social, economic and political potential to the full, and to be able to function positively in theses spheres. Thus, social development seeks to build a humane, caring and peaceful society that upholds welfare rights and enhances people's capacity and self-reliance to enable them to participate fully in all spheres of national life (Estes, 1998; Osei-Hwedie, 1995).

Estes (1998) identifies the various goals of social development as the achievement of a balanced social and economic development; giving high priority to the fullest possible human development; highest possible participation of people in determining the means and goals of development; elimination of absolute poverty; elimination of barriers to development which are used to oppress disadvantaged groups; creating processes that accelerate the pace of development and facilitate the satisfaction of basic needs; and enhancing society's humanistic values based on social justice and the promotion of peace. According to Estes (1998:8), the social development model "seeks to provide a framework for understanding the underlying causes of human degradation, powerlessness and social inequality...." The goal, however, is to "guide collective action towards the elimination of all forms of violence and social oppression".

It is often argued that for developing countries to speed up their process of development, they need technology from the West. This means that developing countries should adapt themselves to the transferred technology and knowledge to improve their economies. However, there is also the contention that, whereas Western knowledge may be essential, it should be compatible with the priorities, and the social and cultural preferences of developing countries. Thus the transferred knowledge should be disengaged from its Western context (Mangaliso et al., 2005).

There have been many changes and shifts regarding the meaning and goals of development. In the 1960s (the First UN Development Decade), the focus was on economic growth and the use 
of scientific and technical knowledge to achieve prosperity in the developing world. It was assumed, amidst great optimism, that the problems of the developing world would be solved through the transfer of technology and scientific knowledge from the West. It was hoped that this would lead to modernisation (Elliot, 2000). By the 1970s (the Second UN Development Decade), inequality within and between countries had worsened. Even where economic growth was achieved, the wealth was not shared equitably among the population and the optimism of the 1960s faded away. At this time, development thinking asserted that underdevelopment was a direct consequence of development elsewhere and the nature of the international capitalist system. It was argued that developing countries are entrenched in the capitalist system and, hence, their underdevelopment. Thus, the international division of labour and not lack of capital or entrepreneurial skill was the cause of underdevelopment (Elliot, 2000).

In the 1980s (the Third UN Development Decade), the focus on development included factors related to distributional issues such as improving income levels. Development was conceptualised as a multidimensional process consisting of widespread improvements in the social and material wellbeing of all in the society. Thus it focused on economic and social activities and also those related to population, natural resources and their impacts on the environment, among others. However, not much was achieved during this period. In fact, the 1980s were termed a period of "development reversal" (Elliot, 2000:13) in the developing world, except for the East Asian newly industrialised countries. In the 1990s many developing countries were saddled with huge debts. Inequality increased and nine of the top ten most indebted countries globally were in Africa (Elliot, 2000). It is under such circumstances that the conception of development has broadened to include the genuine needs of society.

\section{BASIS OF AFRICAN VALUES: UBUNTU/BOTHO}

Over the years African leaders have faced difficult challenges in their efforts to transform their countries. It is in the context of these difficulties that efforts are made to understand indigenous cultures, as a basis for improving the welfare of the people. African values, especially, the latent, unobservable ones culminating in social activities, and referred to as ubuntu in South Africa and botho in Botswana, have become important factors in socio-economic development (Mangaliso, 2005; Mangaliso et al., 2005). For example, ubuntu/botho and related terms have become core organising concepts for developing countries. Thus, Botswana's Vision 2016 seeks to make the country a just and caring; educated and informed; open, democratic and accountable; and moral, ethical and tolerant society by the year 2016 (Presidential Task Group for a Long-Term Vision for Botswana, 1997).

The thought systems of societies usually influence their attitudes and behaviours. Thus ubuntu/botho, the notion of humanness, provides the moral basis for behaviour. Therefore, it is a measure of "what's good or bad, right or wrong, just versus unjust" (Mangaliso et al., 2005:794). It is emphasised that humanness is manifested in relationships, language, processes of decision making, productivity and efficiency, and leadership, among other factors. The quality of ubuntu/botho is based on human interdependence as related to the norms of, and respect for, reciprocity, selflessness and symbiosis. In this sense language "is used to establish a sense of community, belonging, shared heritage, and common welfare". Thus, for example, an important aspect of language (conversation) is to establish and reinforce relationships. Therefore, unity and understanding among groups are valued above efficiency and accuracy in language use (Mangaliso et al., 2005:795).

Under ubuntu/botho decision making becomes an inclusive, community-saturated process, undertaken with deliberateness and flexibility to allow deviations, so as to delve into other 
matters even if they seem remotely connected to the issues under discussion. Issues are looked at from different angles. The goal of decision making, in this context, is to preserve harmony and achieve consensus. Thus, a decision supported by the majority or reached through consensus is seen as superior to the one deemed right but which may be opposed and resented by many (Mangaliso et al., 2005:796). For example, this emerged during the Convention for a Democratic South Africa (CODESA). Despite the numerical advantage of the ANC and its partners, all major decisions were made by consensus, after a lot of discussion to bring other parties into agreement (Mangaliso et al., 2005).

African life is to a greater extent traditionally communal and espouses the values of social solidarity, harmony and cooperation. African religions affirm these values and provide constant support and sanction for the moral obligations associated with them (Gyekye, 2003). Gyekye (2003) emphasises that the religiosity of Africans implies and underlies the limitations and the shortcomings of humans and, thus, the need to depend on God. The awareness and the acceptance of theses limitations lead to humility, which has implications for social, economic and political relations. Thus to do the right thing is a moral as well as a religious obligation.

African societies recognise the dignity of the human being and have a deep concern for human welfare and happiness. The recognition of the value of humanity is intrinsically linked to the recognition of the unity of all people, blood related or not, because all humans are the creation and children of God. Therefore, one can appreciate and demonstrate humanity by showing compassion, generosity and hospitality. This implies being open to the needs, interests and general welfare of others. It also means sharing, mutual aid, caring for others, interdependence, solidarity, reciprocity and social harmony (Gyekye, 2003).

\section{AFRICAN VALUES AND SOCIO-ECONOMIC DEVELOPMENT}

Generally African cultures recognise that human beings have individuality, personal will and unique identities that must be exercised and appreciated. There is reference to, and recognition of, personal responsibility. This is because individual effort is a necessary condition for fulfilling needs and reaching goals. A person is responsible for the kind of life he/she leads, and in many African societies proverbs affirm that "Life is as you make it" (Gyekye, 2003:48). Thus the value of self-reliance is cherished and complete dependence on others is seen as unwise, unhelpful and unacceptable. Again, Gyekye (2003:49) cites several African maxims to support this. For example, "The lizard does not eat pepper for the frog to sweat," and "One does not fan (the hot food) that another may eat". All these point to the value of initiative and responsibility, and the associated rewards.

There is coexistence of both communal and individualistic values, though they may seem opposed. The interaction between the individual and community is basic to an individual's as well as the community's well being. Thus, the individual cannot develop outside the context of the community, and the welfare of the community requires the talents and initiatives of individual members. This is why there are constant efforts to "integrate individual desires and social ideals and demands". Africans, therefore, have two responsibilities: one to the individual him/herself, and the other to the community. They have both responsibility and individual rights. However, these are embedded in a social and not in an individualistic morality (Gyekye, 2003:50). Thus, the emphasis appears to be more on responsibility rather than individual rights which are mutually inclusive rather that dialectically opposed.

African values and philosophies have sometimes been misinterpreted and misused. In the postcolonial era some African leaders took the communal values as an ideological basis for 
socialism. For example, Kwame Nkrumah, the first president of Ghana, asserted that "in socialism, the principles underlying communalism are given expression in modern circumstances" (Nkrumah, 1964:73). Along the same lines Leopold Senghor, former president of Senegal, also emphasised that Africans "had achieved socialism before the coming of the Europeans" (Senghor, 1964:125). Julius Nyerere, former president of Tanzania, also emphasised that "one of the achievements of our society was the universal hospitality on which they could rely" (Nyerere, 1968:5). All these African leaders equated socialism with traditional African communal systems. Such understanding ignores the elements of individuality and personal efforts in the context of communal values, and the fact that individuality and communalism existed side by side.

It is emphasised that notions of private property and private enterprise, associated with individuality, are part of the African social economy. Individuals, families and communities did not rely on chiefs or the state for their economic and social wellbeing and survival. They had their own wealth and property. Thus Gyekye (2003:96) concludes that the African traditional communal system is essentially "socio-ethical, not economic", which defines the relationship between the state, individuals and groups. It is also an arrangement that responds to the needs and wellbeing of individuals.

Socialism, on the other hand, generally, is an economic set-up involving public control of all aspects of the economy. The African system, therefore, is not a basis for a centrally planned and controlled economic system. In the system, for example, individuals can acquire wealth while working on family land. This means that private property stands side by side with public ownership. Also, for example, private property, such as cattle, exists side by side with communal property such as land. It is, therefore, not true that private or individual ownership does not exist in traditional African communal societies and cultures. Generally, Gyekye (2003) identifies two kinds of private ownership: individual and family (cooperate) ownership, coexisting with public ownership. Self-acquired wealth is appreciated in African societies, and the traditional structures accommodated the notions and values of private property. In this context thrift, capital accumulation, efficient management and savings, all core elements of capitalism, are understood, accepted and practised in the traditional African economy. The acquisition of material wealthy is part of the African character, and "the existence of a wealthy person implies the existence of private property" (Gyekye, 2003:99). However, this seems to have been ignored by the advocates of African socialism.

African politicians and academics, especially in the 1960s and 1970s, tried to counter Western philosophies by emphasising that Africans are unique and therefore, different. For example, Nkrumah's "socialism", Senghor's "Negritude", Nyerere's "Ujamaa" and Kaunda's "Humanism" were all attempts to place African values at the heart of socio-economic development for their countries (Nkrumah, 1964; Senghor, 1964; Nyerere, 1968; Kaunda, 1975). These attempts generally failed to achieve any significant results in restructuring society. They did not go far enough. In many instances they were misunderstood and resisted by the people. In addition, the African values which were supposed to be the basis of development efforts were either mixed up with other values or were deliberately misinterpreted and manipulated for political gain.

Despite the failures of earlier attempts, the force of globalisation and dominance of Western values in word development, one cannot help but agree with Agbo (2003:191), who contends that as Africans "we cannot accept the goals of science and Western rationality as the only means to our survival as a people". However, according to Wiredu, quoted in Agbo 
(2003:199), "the African today, as a rule, lives in a cultural flux characterized by a confused interplay between indigenous cultural heritage and foreign cultural legacy of a colonial origin". However, Agbo (2003:201) goes on to contend that "it would be foolhardy to ignore global developments... in the name of cultural self-definition". In view of this, Wiredu quoted in Agbo (2003), calls for, among other things, "conceptual decolonization". Thus, the search for African paradigms, philosophies and indigenous knowledge, among other things, has to be part of this process of decolonisation.

In traditional African societies the basis of governance, a properly constituted and recognised authority, is generally the people, the common people. Thus, there have always been some elements of democracy such as transparency and accountability. Gyekye (2003:110) quotes a French scholar who wrote about governance in central Africa in the $20^{\text {th }}$ century: "Over the free citizens the chief's authority is valid only insofar as it is the mouthpiece of the majority interests, lacking which character it falls to the ground." Gyekye (2003:111) again cites a Briton, who, writing on Central Africa (including Zambia) concluded that "no permanent form of negro government can exist save that based four square on the people's will". A British anthropologist, commenting on the politics of the Ashanti in Ghana, concluded that "in England, the government and the House of Commons stand between ourselves and the making of laws, but among the Ashanti there was not any such thing as government apart from the people" (quoted in Gyekye, 2003:116).

Sebudubudu and Osei-Hwedie (2005), show how the kgotla, a traditional socio-political institution, complements Botswana's modern democracy very well, with its openness and democratic customs. It is a community institution which performs political, administrative and judicial functions. Traditionally, it is a community meeting place to discuss tribal affairs and developmental issues. Since independence it has been used by the government, ministers, members of parliament, civil servants and councillors to explain government policies and programmes to the public, and solicit public views and support, and to mobilise the public in national politics.

\section{NEO-LIBERAL IDEOLOGY}

The neo-liberal economic and political perspective emphasises, among other things, freedom of the individual, and the fact that government action should be aimed at maximising individual and private control and responsibility. It also advocates competitive democracy, pluralism and popular control of the governance machinery. Basically, this perspective calls for a reduced role of government in providing social welfare and managing economic activity (MacEwan, 1999). Advocating private property and the free market at every level of society by neo-liberals is justified on the grounds that liberty and efficiency are connected and that free exchange of trade maximises the welfare of those involved or concerned, as it allows them to specialise in their areas of interest or comparative advantage. It is assumed that people differ in their preferences and this partly accounts for inequalities between individuals. These inequalities, however, are seen as a necessary price one has to pay for individual liberty. In addition, if people have a difference of opinion or moral standards different from the rest of the population, they are free to express these (Kabber \& Humphrey, 1991).

Neo-liberalism as an economic policy became dominant in most of the world during the final decades of the $20^{\text {th }}$ century. It has given greater reign to unregulated, private decision making. The ideas at the foundation of this policy come directly from the classical economic liberalism that emerged in the $19^{\text {th }}$ century and proclaimed "the market" as the proper guiding instrument by which people should organise their economic lives. While the basic tenets of neo-liberalism 
operate in rich countries, the policy plays its most important role in many of the low-income countries of Latin American, Africa, Asia, and Central and Eastern Europe. Within these countries influential groups see their fortunes tied to neo-liberalism, but the conflict over economic policy is seldom confined within a nation's borders. Officials from the international lending agencies, particularly the IMF and World Bank; the governments of the economically advanced countries, particularly the United States of America; and private firms operating internationally use their economic and political power to foist market-oriented policies on the people of the low-income countries (MacEwan, 1999).

Critics of neo-liberalism often argue that the rise of market-oriented policies is a major obstacle to democratic economic development. By reducing explicit social regulation of private economic activity and "leaving things to the market", neo-liberalism prevents the implementation of programmes that would allow people to solve their own economic problems and serve the material needs of the great majority. Popular development activities which are not market oriented are not encouraged or supported. Also direct efforts by the governments to provide employment through, for example, public works programmes or public enterprises are not implemented because, in a neo-liberal scheme of things, productive activity must be left in the hands of the private sector. Again, heavy investments in health care and educational programmes run contrary to the prescription of a minimal role for the government in socioeconomic affairs (MacEwan, 1999).

Other criticisms relate to the fact that, for example, programmes to preserve the stability of local communities, in both rural and urban settings, are greatly hampered because the market has no way of valuing the social bonds of community life, and thus they have no role in a neoliberal programme. Expansion of programmes such as literacy and other educational projects are hampered because they require the public sector to play a major role and make investments. In spite of the fact that it prevents the adoption of these sorts of democratic development programmes, which meet the basic need of the majority, neo-liberalism continues to define the policy agenda in many countries (MacEwan, 1999).

\section{NEO-LIBERALISM, AFRICAN VALUES AND DEVELOPMENT}

The challenges facing African societies in their efforts at development include the question as to whether Afro-centrism offers enough on development processes based on theories, values and technologies emanating from relevant knowledge about themselves. Thus, can a new development paradigm, consistent with, or accommodating of, African values and views of development be created? The fundamental questions raised about the sustainability and desirability of the dominant Western model of development means Africans are faced "with an awesome development challenges" (Baylis \& Smith, 2005:666). Baylis and Smith (2005:667) contend that "if sub-Saharan Africa continues on its current courses, it will take another 150 years to reach the MDG (Millennium Development Goal) target of halving poverty".

However, the idea of "the interconnected world" (Rajaee, 2000:98) means that it is necessary to formulate a new framework of understanding and undertaking social development which effectively combines local and universal values and processes. The basic challenge, therefore, is to formulate a theory of development that accepts the local and the universal as equally important. Thus, practical solutions are necessary to moderate the countervailing forces of local and Western values. Such solutions must be sensitive to the local socio-cultural environment, and able to effectively explore the cultural and environmental variables. "It requires constant learning ... not merely acquiring information ...nor is it learning to recognize 
some specific invitations to encounter particular adventures in human self-understanding" (Oakeshott, quoted in Rajaee, 2000:130).

Afro-centrism calls for alternative perspectives on development and on popular notions of poverty. The orthodox conception of poverty, for example, refers to a situation where people have no money to buy adequate food or satisfy other basic needs. This understanding has arisen as a result of globalization of Western culture and associated expansion of the market. Thus, communities which provide for themselves outside wage labour and monetized cash transactions such as hunter-gatherer societies are regarded as poor (Rajaee, 2000). This has also led to the popular notion of the poor surviving on less than U\$1 or 2 a day.

However, a critical alternative views of poverty does not simply put emphasis on money, but "on spiritual values, communities, and availability of common resources" (Baylis \& Smith, 2005:648). Such an alternative view of poverty has also led to alternative perception of development as centred broadly on entitlements and redistribution, and incorporates maters of democracy such as political empowerment, participation, meaningful self-determination and protection of the commons, among others (Baylis \& Smith, 2005).

Alternative views of development, therefore, see poverty as a situation where people cannot provide for themselves through their own efforts. Thus, development entails creating "human well-being through sustainable societies in social, cultural, political, and economic terms" (Baylis \& Smith, 2005:650). The achievement of this is through bottom-up, participatory and self-reliant approaches and based in the main on appropriate (often local) technology and knowledge. Thus, community participation, equity and empowerment become critical aspects of development.

On the surface it appears that afro-centrism and neo-liberalism are incompatible. However, the foregoing discussion on African values and processes indicate otherwise. Often the argument is about whether traditional cultural values can play an effective role in contemporary development. It is acknowledged and emphasised that there are several features of African cultural values that cannot be considered worthwhile for the purposes of modern life. However, it is equally true that African values have many positive features and with the relevant modifications, amendments and refinements can contribute a great deal to life in the modern world. Such African values as humanity and communalism recognise the dignity and integrity of human beings. In this sense common brotherhood is linked to common humanity. The value of communalism and individualism is expressed through the sharing of common social life, commitment to the common goal, appreciation and respect for mutual obligation, interdependence and solidarity. It recognises individuality but urges the avoidance of extreme individualism, while attempting to balance and harmonise communalism and individualism to enable the two to co-exist. Morality and responsibility, in the African context, are social and non-individualistic, and are associated with a preoccupation with human wellbeing, based on the notion that all humans deserve to be helped (Gyekye, 2003).

The contention is that, generally, the traditional African society is a welfare state which functions on the basis of fair, but not necessarily equal, distribution. People have general access to societal resources granted to all, but not on a socialist or communist basis in any Marxian sense. Traditional African societies also recognise and appreciate human rights. The roots of human rights, such as individuality, personal responsibility, dignity and integrity of all people, free expression of opinion, right to fair trial, right to food and protection from hunger, and the right to own property are generally acknowledged and practiced (Gyekye, 2003). In this sense, therefore, African traditional values do accommodate major elements of neo- 
liberalism and vice versa. Thus, it may be concluded that that African values such as ubuntu/botho are useful tools for the development of contemporary African societies. However, these are situated in a community context.

\section{CONCLUSION}

The neglect of African values in the developmental debate and process is misplaced. It is evident that African values of ubuntu/botho are compatible with the modern neo-liberal orientation of development, and are being used in African countries with neo-liberal economies such as Botswana. What remains, therefore, is a critical evaluation, appreciation and ultimately effective incorporation in the development process if Africa has to boost its chance of development and meet the welfare challenges of its people.

\section{BIBLIOGRAPHY}

AGBO, J. 2003. Africa within the globe: Confronting the parameters of cross cultural philosophy. Journal of Cultural Studies, 5(2):182-213.

AHLUWALIA, P. \& NURSEY-BRAY, P. 1997. Post colonialism: Culture and identity in Africa. Commack, NY: NOV Science Publishers, Inc.

ASANTE, M.K. 1980. Afrocentricity: The theory of social change. Buffalo, New York: Amulefi.

ASANTE, M.K. 1998. The Afrocentric idea. Philadelphia: Temple University Press.

ASANTE, M.K. 1999. The painful demise of Eurocentricism: Trenton, NJ: Africa World Press, Inc.

BAYLIS, J. \& SMITH, S. 2005. The globalization of world politics: An introduction to international relations $\left(3^{\text {rd }}\right.$ ed). Oxford: Oxford University Press.

DOMINELLI, L. 1997. Social work and social development: A partnership in social change. Journal of Social Development in Africa, 12(1):29-38.

ECONOMIC COMMISSION FOR AFRICA (ECA). 2005. The millennium development goals in Africa: Progress and challenges. Available: http://www.uneca.org/mdgs/MDGS. [Accessed: 14 October 2006].

ELLIOT, J.A. 2000. An introduction to sustainable development $\left(2^{\text {nd }}\right.$ ed). London: Routledge.

ESTES, R.J. 1998. Developmental social work: A new paradigm for a new century. Paper Presented at the $10^{\text {th }}$ International symposium of the Inter-University Consortium for International Social Development (IUCISD) Cairo, Egypt. June 28 - July 2.

GRAY, M. \& ALLEGRITTI, I. 2002. Cross-cultural practice and the indigenisation of African social work. Social Work/Maatskaplike Werk, 38(4):324-336.

GRAY, M., MAZIBUKO, F. \& O’BRIEN, F. 1996. Social work education for social development. Journal of Social Development in Africa, 11(1):33-42.

GYEKYE, K. 2003. African cultural values: An introduction. Accra: Snakofa Publishing Company.

KABBER, N. \& HUMPHREY, J. 1991. Neo-liberalism, gender, and the limits of the market. In: COLCLOUGH, C. \& MANOR, J. (eds). States or markets: Neo-liberalism and the development policy debate. Oxford: Clarendon Press. 
116

KAUNDA, K.D. 1975. Humanism in Zambia and a guide to its implementation, Part 1. Lusaka: Zambia Information Service.

MacEWAN, A. 1999. Neo-liberalism or democracy? Economic strategy, markets, and alternatives for the $21^{\text {st }}$ Century. Sydney: Pluto Press.

MANGALISO, M.P. 2005. Cultural mythology and leadership in South Africa. Symposium Presentation at the Organizational Strategy and Operations Domain, Eastern Academy of Management- International Managing in a Global Economy XI, Cape Town, South Africa: 585-588.

MANGALISO, M.P., MANGALISO, N.A. \& WEIR, D.T.H. 2005. Dimensions of traditional and Emergent Management Styles in Southern Africa and Northern Africa/Middle East. Paper presented at the Eastern Academy of Management Conference on Managing in a Global Economy. Cape Town, South Africa: 792-809.

MIDGLEY, J. 1986. Community participation, social development and the state. London \& New York: Methuen.

MIDGLEY, J. 1995. Social development. London: Sage Publishers.

NKRUMAH, K. 1964. Conscientism. London: Heinemann.

NYERERE, J.K. 1968. Ujamaa: Essays on socialism. Dar Es Salaam: Oxford University Press.

OSEI-HWEDIE, K. 1995. A search for legitimate social development education for Africa. Lewiston, New York: Edwin Mellen.

PRESIDENTIAL TASK GROUP FOR A LONG-TERM VISION FOR BOTSWANA. 1997. Vision 2016: Long term vision for Botswana: Towards prosperity for all. Gaborone: Government Printer.

RAJAEE, F. 2000. Globalization on trial. The human condition and the information civilization. Ottawa: International Development Research Centre (IDRC).

SCHIELE, J.H. 2000. Human services and Afrocentric paradigm. New York: The Haworth Press.

SEBUDUBUDU, D. \& OSEI-HWEDIE, B.Z. 2005. Pitfalls of parliamentary democracy in Botswana. Gaborone: Department of Political and Administrative Studies. University of Botswana.

SENGHOR, L. 1964. On African socialism (transl by Mercer Cook). New York: Praeger. YIMAN, A. 1990. Social development in Africa 1950-1985. Aldershot: Avebury.

Prof Kwaku Osei-Hwedie, Department of Social Work, University of Botswana, Gaboron, Botswana. 